\title{
Factors That Affect Post-traumatic Growth in Korean Police Officers, by Age Group
}

\author{
Myung-Gwan Kim \\ Kyungpook National University \\ Seungwoo Han ( $\square$ swhan@kiu.ac.kr ) \\ Kyungil University
}

\section{Research article}

Keywords: Post-traumatic growth, Korean police officers, age, Health policy

Posted Date: December 15th, 2020

DOI: https://doi.org/10.21203/rs.3.rs-126806/v1

License: (c) (i) This work is licensed under a Creative Commons Attribution 4.0 International License. Read Full License 


\section{Abstract}

Background: The aim of this study was to identify factors that influence PTG in South Korean police officers, according to age group.

Methods: Raw data were collected from September 26 to October 9, 2017 for 269 police officers who are employed at 10 police offices in Seoul. Multiple regression analysis was conducted on selected data by age group.

Results: Post-traumatic growth (PTG) was affected significantly by age, marital status, monthly income, and police rank in pain perception and social support variables among general characteristics. Factors that affected PTG in the '20 29' age group were resilience (B $=0.570)$ and pain perception ( $B=0.243)$, but in the ' $30 \sim 39$ ' age group, only Pain perception ( $B=0.249$ ) was significant, and in the 'over 50 ' age group, social support $(B=0.448)$ and pain perception $(B=0.252)$ were significant.

Conclusion: Development of mental health programs should consider the age group of the patients. Mental health care should also be continuous.

\section{Background}

Police officers are exposed to a variety of traumatic events, which can be physical or psychological. Post-Traumatic Stress Disorder (PTSD) is common. However, after experiencing trauma, not everyone experiences post-traumatic stress, and most people try to overcome trauma, and move on to a more positive direction.

Post-Traumatic Growth (PTG) is a life-threatening variety of physical, and psychological trauma, which is positive psychological change after struggle associated with traumatic circumstances[1]. This is not just a recovery of physical and psychological functions that the person had before the traumatic experience, but also a change in life awareness[2]. In the process of experiencing and overcoming trauma, the adaptive aspect of the individual and the strength of the internal strength of the individual will lead to a change in healthy life and will affect the recovery of the pretrauma adaptation level. In recent years, research on PTG has begun, with a focus on personal aspects such as well-being, quality of life, and the therapeutic approach to psychological interventions[3]. Further studies should consider PTG by people who are in occupations that experience traumatic events in greater number and intensity than other occupations.

However, the demographic variables used have not been consistent. Some previous studies used gender as a demographic variable. For example, studies of PTG of police officers[4] and New Zealand Surf Lifesavers [5] have shown better PTG in females than in males. However, in this study, we group subjects according to demographic variables, and identify how factors that affect PTG differ among the groups. Then we use the insights to guide search for effective ways to help people to cope with stress, and to improve the job environment.

The age at which the subject experienced the trauma was considered in previous research[6], in which conflicts arising from various events lead to experiences such as peritraumatic distress, impact of event and depression. Among them, resilience has an effect on PTG. Resilience is dynamic and persistent, so it interacts with various psychological and environmental factors while the subject overcomes and adapts to adversity[7]. People with high resilience are less likely to perceive pain because they have a better ability to cope with events than those who do not have high resilience[8]. Therefore, people with a high resilience are less likely to experience psychological disturbances, and recover better than people who have low resilience. The internal confusion state can be newly restructured in a balanced state. This process can accelerate the experience of growth through the turbulent situation created by the traumatic experience and subsequent rebuilding of schemas as resistant to traumas[9]. Social support can also help subjects to cope with stressful situations, and in psychological adjustment[10], by interaction with peers. Positive feedback provided by others can help to overcome the trauma of a life-threatening attack[11]. The perception of pain also be regarded as an important variable that affects PTG. The degree of post-traumatic experience varies according to the degree of pain perception in relation to trauma experience and pain perception[12]. The degree of perception of pain is fairly subjective, and a study of the extent to which individuals experience a traumatic perception of traumatic experiences and the degree of post-traumatic experience suggests that the experience of PTG increases with increase in the perceived severity of the trauma [12]. Therefore, the goal of this study was to provide basic data for the development of a program that can confirm the clinical value by exploring various variables associated with PTG of police officers, and to promote PTG in the high-risk group.

\section{Methods}

\section{Research subjects}

The subjects of this study were regular police officers who work at the department of life safety of 10 police stations out of 31 police stations in 25 districts of Seoul, excluding $\mathrm{G}$ district. The purpose and method of the research were explained to the head of the department. Thirty-five subjects were selected from each of the 10 stations.

\section{Data collection}


This study was approved by K University Bioethics Committee (2017-0104). The data were collected from September 26, 2017 to October 9, 2017. The researcher visited the police station and conducted the survey only with police officers who agreed to participate. The researchers explained that the results of the survey would be processed numerically. Before the subjects were asked to complete the questionnaire, the researcher explained the purpose of the research, and the method of the measurement. The questionnaire was completed after receiving the written consent of the subject.

\section{Measurement tools}

\section{Recovery resilience}

Resilience measured recovery capability [13], using analysis of 27 items. Each item was graded on a 5-point Likert scale with a score of 1 for 'not quite at all' and a score of 5 for 'strongly agree'. These items include three subfactors: controllability ( 9 items), affirmative ( 9 items) and sociality ( 9 items). In preliminary analysis, these results received Cronbach's a $=0.90$.

\section{Pain perception}

The evaluation of pain perception was a modified version of the method in [16], which was derived from [14] and [15]. The questionnaire consisted of five items that were rated on a 5-point Likert scale and 4 items on the from 0 ("not at all") to 5 ("frequently"), (5 items), sleep disturbance and emotional paralysis, and dissociation symptoms ( 5 items). The assessed perception of pain increases with increase in the score. The items had Cronbach's $a=0.97$.

\section{Social support}

The assessment of social support is derived from the revised version of the Multidimensional Scale of Perceived Social Support (MSPSS) [17], and the revised version was a modified version of [18].This assessment consists of 12 items that measure family support (four items), friend support (four items) and meaningful support of others (four items); the assessments are rated on a 7-point Likert scale, from $1=$ 'Absolutely not' to $7=$ 'Absolutely agree'. The assessed degree of social support increases with increase in the score. In this study, the items had Cronbach's a $=0.95$.

\section{PTG}

The rating scheme for PTG used [19] and a revised and supplemented Korean version of the Posttraumatic Growth Inventory (K-PTGI) [20]. This scheme measures 16 sub-factors: self-perception change, new possibility change, interpersonal relationship change, spiritual change. Each item was rated on a 6-point Likert scale from 0 = "not experiencing these changes" to $5=$ "very frequently experienced". Again, the assessed PTG increased with increase in this score. In this study, the items had Cronbach's $a=0.95$.

\section{Data Analysis}

In this study, the general characteristics and research variables of the subjects were analyzed using descriptive statistics. Multiple regression analysis was performed by dividing the gender into the factors that affect PTG. In addition, a radial graph of the factors was used based to determine the extent to which the age of police officers affected the PTG. Analysis was conducted using open source statistical software R 3.5.0; statistical significance was declared at $p<0.05$.

\section{Results}

Marital status changed consistently with increase in age of the subjects. The percentage who were married was 0 in subjects who were in their twenties, 50 in subjects who were their thirties, 94.4 in subjects who were in their forties, and 98.1 in subjects who were in their fifties.

Income also increased with age. Of the subjects who were in their $20 \mathrm{~s}, 81.4 \%$ earned 2-3 million won per month; of those in their $30 \mathrm{~s}$, 78.7\% earned 2-3 million won per month; of those in their 40 s, $66.7 \%$ earned between 3 and 4 million won per month, and of those over 50 , $61.5 \%$ earned over 4 million won per month.

The most common 'highest education level' generally with subject age. Of subjects in their 20 s, $55.9 \%$ had only finished high school (55.9\%); for those in their $30 \mathrm{~s}, 62.3 \%$ had graduated from university; and for those in their $40 \mathrm{~s}, 58.3 \%$ had graduated from university.

Ranks also increased with age. Of subjects in their $20 \mathrm{~s}$ and $30 \mathrm{~s}$, most were constables ( $84.7 \%$ and $45.1 \%$, respectively); of subjects in their $40 \mathrm{~s}$, $47.2 \%$ were lieutenants and $47.2 \%$ were sergeants; of subjects over $50,98.1 \%$ were lieutenants (Table 1 ). 
Table 1

General Characteristics of Subjects

\begin{tabular}{|lllll|}
\hline Variable & 20-29yrs & 30-39yrs & 40-49yrs & $\geq 50 y r s$ \\
\hline Marital state & & & & \\
\hline Married & $3(5.1)$ & $61(50.0)$ & $34(94.4)$ & $51(98.1)$ \\
\hline Single & $56(94.9)$ & $61(50.0)$ & $2(5.6)$ & $1(1.9)$ \\
\hline Monthly income & & & & \\
\hline$\geq 4$ million won & $0(0.0)$ & $1(0.8)$ & $9(25.0)$ & $32(61.5)$ \\
\hline 3-4 million won & $0(0.0)$ & $17(13.9)$ & $24(66.7)$ & $19(36.5)$ \\
\hline 2-3 million won & $48(81.4)$ & $96(78.7)$ & $3(8.3)$ & $1(2.0)$ \\
\hline <2 million won & $11(18.6)$ & $8(6.6)$ & $0(0.0)$ & $0(0.0)$ \\
\hline Education level & & & & \\
\hline University & $23(39.0)$ & $76(62.3)$ & $21(58.3)$ & $17(32.7)$ \\
\hline College & $3(5.1)$ & $16(13.1)$ & $8(22.2)$ & $12(23.1)$ \\
\hline High school & $33(55.9)$ & $30(24.6)$ & $7(19.4)$ & $23(44.2)$ \\
\hline Police rank & & & & $1(1.9)$ \\
\hline Lieutenant & $1(1.7)$ & $5(4.1)$ & $17(47.2)$ & $51(98.1)$ \\
\hline Sergeant & $1(1.7)$ & $15(12.3)$ & $17(47.2)$ & $1(1.9)$ \\
\hline Corporal & $7(11.9)$ & $14(38.5)$ & $1(2.8)$ & $0(0.0)$ \\
\hline Constable & $50(84.7)$ & $55(45.1)$ & $1(2.8)$ & $0(0.0)$ \\
\hline Total & $59(100.0)$ & $122(100.0)$ & $36(100.0)$ & $52(100.0)$ \\
\hline * Subjects are male police officers -Unit: Frequency (\%) & \\
\hline & & & & \\
\hline
\end{tabular}

The distributions differed among the major variables. Resilience had a minimum $(\min )=75$, $\operatorname{maximum}(\max )=135$, $\operatorname{mean}=103.32$, standard deviation $(\mathrm{sd})=10.59$, skewness (skew) $=0.043$, and kurtosis (kurt) $=1.597$. The pain perception had $\min =0, \max =85, \operatorname{mean}=25.27, \mathrm{sd}=18.60$, skew $=0.581$, and kurt $=2.701$. Social support had $\min =35, \max =85$, mean $=56.53, \mathrm{sd}=9.90$, skew $=-253$, and kurt $=2.276$. PTG had $\min =10$, maximum $=75$, mean $=44.56, \mathrm{sd}=12.46$, skew $=-0.504$, and kurt $=2.069$ (Table 2$)$.

Table 2

Level of Descriptive statistics for Study Variables

\begin{tabular}{|lllll|}
\hline Variable & Min-Max & $M(S D)$ & Skewness & Kurtosis \\
\hline Resilience & $75-135$ & $103.32(10.59)$ & .043 & 1.597 \\
\hline $\begin{array}{l}\text { Pain } \\
\text { perception }\end{array}$ & $0-85$ & $25.27(18.60)$ & .581 & 2.701 \\
\hline $\begin{array}{l}\text { Social } \\
\text { support }\end{array}$ & $35-72$ & $56.53(9.90)$ & -.253 & 2.276 \\
$\begin{array}{l}\text { Post-traumatic } \\
\text { Growth }\end{array}$ & $10-75$ & $44.56(12.46)$ & -.504 & 2.069 \\
\hline M = Mean value, (SD) = Standard Deviation & & \\
\hline
\end{tabular}

None of the general characteristics showed differences in resilience.

The score of pain perception increased with age, from 17.92 in the $20 \mathrm{~s}$ age group, 23.51 in the $30 \mathrm{~s}, 32.83$ in the $40 \mathrm{~s}$ and 32.52 in the $50 \mathrm{~s}$ or older. The score was 20.84 for single subjects and 28.84 for married subjects. Monthly income also affected pain perception: it was highest (31.57) in 
those who earned 4 million won per month, and the score of pain perception was the highest, compared to 18.16 in the $2-3$ million income group. The score of pain perception generally increased with the rank of the police officer, and was highest in sergeants.

The score of social support decreased as age increased, from 60.83 in the 20 s to 52.88 in the 50 s or older. It was lower in married officers (55.33) than in single officers (58.03). The score of social support decreased as income increased. The rank was the highest in social support with 59.63 points in the lowest rank. The general characteristics had no significant differences on PTG (Table 3).

Table 3

Variables related to General Characteristics

\begin{tabular}{|c|c|c|c|c|c|c|c|c|}
\hline \multirow[t]{2}{*}{ Variable } & \multicolumn{2}{|l|}{ Resilience } & \multicolumn{2}{|l|}{$\begin{array}{l}\text { Pain } \\
\text { perception }\end{array}$} & \multicolumn{2}{|l|}{$\begin{array}{l}\text { Social } \\
\text { support }\end{array}$} & \multicolumn{2}{|l|}{$\begin{array}{l}\text { Post-traumatic } \\
\text { Growth }\end{array}$} \\
\hline & $M(S D)$ & t or $F(p)$ & $M(S D)$ & t or $F(p)$ & $M(S D)$ & t or $F(p)$ & $M(S D)$ & t or $F(p)$ \\
\hline \multicolumn{9}{|l|}{ Age group } \\
\hline 20-29yrs & $105.86(9.90)$ & $2.070(.105)$ & $17.92(15.45)$ & $8.760(<.001)$ & 60.83(8.93) & $7.566(<.001)$ & $44.10(13.51)$ & $.374(.772)$ \\
\hline $30-39 y r s$ & $103.43(10.98)$ & & 23.51(17.74) & & $56.83(9.83)$ & & 43.95(12.00) & \\
\hline $40-49 y r s$ & $101.28(10.23)$ & & $32.83(19.83)$ & & $53.75(10.37)$ & & $45.58(14.03)$ & \\
\hline$\geq 50 y r s$ & $101.60(10.31)$ & & $32.52(19.11)$ & & $52.88(8.99)$ & & $45.80(11.34)$ & \\
\hline \multicolumn{9}{|l|}{$\begin{array}{l}\text { Marital } \\
\text { state }\end{array}$} \\
\hline Married & $102.79(10.20)$ & $929(.354)$ & 28.84(19.47) & $3.583(<.001)$ & $55.33(9.94)$ & $2.237(.026)$ & $45.66(12.23)$ & $1.620(.106)$ \\
\hline Single & 103.99(11.06) & & 20.84(16.49) & & $58.03(9.68)$ & & 43.19(12.66) & \\
\hline \multicolumn{9}{|l|}{$\begin{array}{l}\text { Monthly } \\
\text { income }\end{array}$} \\
\hline $\begin{array}{l}\geq \\
4 \text { million } \\
\text { won }\end{array}$ & 101.33(9.18) & $.641(.589)$ & $31.57(15.44)$ & $6.323(<.001)$ & $52.67(8.62)$ & 3.663(.013) & 45.12(11.98) & $1.173(.321)$ \\
\hline $\begin{array}{l}3- \\
4 \text { million } \\
\text { won }\end{array}$ & $103.30(10.75)$ & & $31.07(21.23)$ & & $55.33(10.33)$ & & $46.75(12.78)$ & \\
\hline $\begin{array}{l}2- \\
3 \text { million } \\
\text { won }\end{array}$ & $103.26(10.58)$ & & $18.16(19.50)$ & & $58.32(11.48)$ & & $41.46(11.12)$ & \\
\hline $\begin{array}{l}<2 \text { million } \\
\text { won }\end{array}$ & 103.91(10.92) & & $22.05(17.16)$ & & $57.89(9.58)$ & & $43.91(12.60)$ & \\
\hline \multicolumn{9}{|l|}{$\begin{array}{l}\text { Education } \\
\text { level }\end{array}$} \\
\hline University & $102.28(9.84)$ & $1.067(.346)$ & $28.46(20.95)$ & $.670(.513)$ & $54.44(10.79)$ & 1.028(.359) & $45.36(12.88)$ & $.578(.562)$ \\
\hline College & $104.25(10.97)$ & & 24.71(18.37) & & $56.94(9.99)$ & & 45.09(11.89) & \\
\hline $\begin{array}{l}\text { High } \\
\text { school }\end{array}$ & $102.40(10.31)$ & & 24.76(17.95) & & $56.81(9.36)$ & & 43.44(13.16) & \\
\hline \multicolumn{9}{|l|}{$\begin{array}{l}\text { Police } \\
\text { rank }\end{array}$} \\
\hline Lieutenant & $102.29(11.02)$ & $17.768(.154)$ & $30.59(21.55)$ & $12.331(<.001)$ & $55.47(11.13)$ & $6.723(<.001)$ & $46.29(13.98)$ & $.993(.397)$ \\
\hline Sergeant & 101.53(9.79) & & $33.41(18.11)$ & & 53.38(8.99) & & $45.74(11.66)$ & \\
\hline Corporal & 103.07(11.49) & & 24.91(18.48) & & $55.45(9.40)$ & & $42.43(11.70)$ & \\
\hline Constable & $105.04(10.38)$ & & 18.08(15.01) & & $59.63(9.58)$ & & $44.28(12.87)$ & \\
\hline
\end{tabular}

Resilience and pain perception were inversely correlated with the main variables, and social support and PTG were positively correlated with them (Table 4). 
Table 4

Correlations among Variables

\begin{tabular}{|c|c|c|c|c|}
\hline Variable & $\begin{array}{l}\text { Resilience } \\
r(p)\end{array}$ & $\begin{array}{l}\text { Pain } \\
\text { Perception } \\
\text { r (p) }\end{array}$ & $\begin{array}{l}\text { Social } \\
\text { Support } \\
\text { r (p) }\end{array}$ & $\begin{array}{l}\text { Post-traumatic } \\
\text { Growth } \\
\text { r (p) }\end{array}$ \\
\hline Resilience & 1 & & & \\
\hline $\begin{array}{l}\text { Pain } \\
\text { perception }\end{array}$ & $-.318(<.001)$ & 1 & & \\
\hline $\begin{array}{l}\text { Social } \\
\text { support }\end{array}$ & $.586(<.001)$ & $-.280(<.001)$ & 1 & \\
\hline $\begin{array}{l}\text { Post-traumatic } \\
\text { Growth }\end{array}$ & $.223(<.001)$ & $.239(<.001)$ & $.200(<.001)$ & 1 \\
\hline \multicolumn{5}{|c|}{ Pearson Correlation Coefficient Analysis, $r=$ Pearson Correlation Coefficient } \\
\hline$p=$ significant le & rel's for $p$ value, & eject of null hypo & thesis level is $p$ & $>.05$ \\
\hline
\end{tabular}

The effects of general characteristics and measured factors on PTG were analyzed using multiple regression analysis, and then expressed as radial graphs (Fig. 1-4).

The significant factors differed among the age groups. In subjects in their $20 \mathrm{~s}$, resilience was the largest factor that affected PTG (B $=0.570$ ), followed by pain perception ( $\mathrm{B}=0.243$ ); social support did not have a significant effect. In subjects in their $30 \mathrm{~s}$, only pain perception affected PTG $(B=0.249)$. In subjects in their $40 \mathrm{~s}$, none of the factors had a significant effect on PTG. In subjects over 50 , social support was the most significant factor for PTG $(B=0.488)$, followed by pain perception $(B=0.252)$.

\section{Discussion}

The purpose of this study is to investigate the effects of resilience, pain perception, and social support on PTG in police officers in the life-safety field, who work at the front line of crime prevention and social safety in the community. The present study detected that in subjects who were in their $20 \mathrm{~s}$, resilience and pain perception affected PTG, but social support was not a factor. The strong effect of resilience on PTG in the $20 \mathrm{~s}$ is consistent an earlier study of [21] that showed that resilience influenced PTG promotion variables in college students in their $20 \mathrm{~s}$. This agreement in conclusions suggests that people who experience traumatic events at this relatively young age can positively cope with it [22]. The likelihood of recovering to the pre-trauma adaptation level increases with increase in resilience, and the experience of trauma events can be a positive factor in adapting and overcoming difficulties in life. Therefore, police officers must consider resilience as a predictor of various crisis interventions.

In subjects in their $20 \mathrm{~s}$, pain perception also affected PTG. The effects of pain on individuals are psychologically and physically subjective. In previous studies, the degree of perception of pain provided an opportunity for emotional growth[23]. The perception of suffering after the trauma event may drive attempts by the sufferer to reconstruct his or her inner beliefs and values, and to pursue the discovery of a new life path to positively understand the experience of suffering[24]. These results are consistent with previous studies[21] of the relationship between pain perception and PTG in college students in their $20 \mathrm{~s}$.

The experience of pain perception helps to maintain and promote PTG. The experience of suffering in the $20 \mathrm{~s}$ is a continual review of the meaning of the event, and may yield an attempt to overcome the negative emotions more positively, rather than developing the perception of pain as posttraumatic stress. Few studies have considered the effects of pain perception on PTG according to age, so this possibility cannot yet be generalized. However, a study of PTG in adults in their 20 s showed a significant correlation between PTG and aggressive coping strategies. A young person may be more likely than an old person to positively sublimate the perception of pain according to the trauma event. The results of this study suggest the variables that affect PTG should be identified using a multi-dimensional approach that considers various demographic variables such as age and sex.

In subjects who were in their $30 \mathrm{~s}$, pain perception affected PTG, but resilience and social support did not. This result suggests that the level of growth depends on subjective perception level. The police officers in their $30 \mathrm{~s}$ are as likely to experience pain perception as they did as in their $20 \mathrm{~s}$. The individuals may not be trying to overcome the pain by returning to the trauma experience but rather to seek the meaning and help obtained from the pain perception, and to control the pain, and pursue a positive level of change[25]. 
In this study, social support and pain perception affected the PTG, with social support having the greatest effect. A previous study[26] found that PTG was better perceived by those who had experienced trauma and good social support; i.e., that active interaction with the outside world may help a person to develop psychological strategies to cope with the trauma, and thereby overcome the painful situation and develop their life positively[27, 28]. Therefore, social support can be regarded as a significant factor in PTG.

Finally, in subjects who were 50 or older, pain perception affected PTG, is it did for subjects in their $20 \mathrm{~s}$ and $30 \mathrm{~s}$. This result may occur is because the perception of pain caused by traumatic experiences is not overcome with time, but rather promotes an improved level of growth by seeking new meanings and positive thinking about trauma events[29].Therefore, pain perception can be regarded as an important parameter for PTG.

This study has detected that resilience and pain perception have important effects on PTG in police officers in their $20 \mathrm{~s}$, and that pain perception has effects in their $30 \mathrm{~s}$. In officers who were in their $40 \mathrm{~s}$, none of the factors tested influenced PTG.

The results of this study suggest that study of PTG should consider a wide range of variables. For example, such a study might reveal factors that other than resilience, pain perception, and social support that affect PTG in subjects who are in their the $40 \mathrm{~s}$. The approach should be multifaceted and consider the demographic characteristics, occupational, and environmental characteristics of each age group.

\section{Conclusion}

The Commission selected male police officers who work in the life safety department of 10 police stations in Seoul and used them to analyze 269 data out of a total of 300 . Resilience, pain perception, and social support were selected as independent variables and PTG as a dependent variable. The results of this study showed that resilience in the $20 \mathrm{~s}$, pain perception in the $30 \mathrm{~s}$, and social support in the $50 \mathrm{~s}$ have the greatest effect on PTG, and none of the factors tested affected PTG in the $40 \mathrm{~s}$.

The results of this study show the necessity of considering the factors that affect PTG of police officers, and to consider various demographic characteristics. The development of various intervention programs and counseling and customized case management for high-risk could reduce the negative stress response of police officers, and improve PTG.

\section{Abbreviations}

PTSD: Post Traumatic Stress Disorder; PTG: Post-Traumatic Growth.

\section{Declarations}

\section{Ethics approval and consent to participate}

The subject was asked to agree on the survey before the study began.

\section{Consent for publication}

Not applicable.

\section{Availability of data and materials}

The datasets used and/or analysed during the current study are available from the corresponding author on reasonable request.

\section{Competing interests}

The authors declare that they have no competing interests.

\section{Funding}

The researchers received no financial support for this paper.

\section{Authors' contributions}

MG performed statistical analyses and drafted the manuscript. SW contributed to the conception and design of the study as well as statistical analyses. SW and MG critically revised and reviewed the manuscript. All authors read and approved the final manuscript.

\section{Acknowledgements}

The authors would like to thank the police officer for cooperation in the research. It is believed that this study will provide basic data on the development of the police officer's health promotion and psychological support program. The study will also provide an alternative to reducing 
post-traumatic stress for South Korean police officers.

\section{References}

1. BarringtonAJ, Shakespeare-FinchJ. Working with refugee survivors of torture and trauma: An opportunity for vicarious post-traumatic growth. Counsel Psychol Q. 2013;26(1):89-105.

2. Lowe SR, Manove EE, Rhodes JE. Posttraumatic stress and posttraumatic growth among low-income mothers who survived Hurricane Katrina. J Consult Clin Psychol. 2013;81(5):877-889. https://doi.org/10.1037/a0033252

3. Sim BY, Lee YW, Kim H, Kim SH. Post-traumatic growth in stomach cancer survivors: Prevalence, correlates and relationship with health-related quality of life. Eur J Oncol Nurs. 2015;19(3):230-236. https://doi.org/10.1016/j.ejon.2014.10.017

4. Monica L, Anna M, Khachatur S, Olivia S, Leonie A, Michael EA, John MV, and Erin CM. Stressful life events and posttraumatic growth among police officers: A cross-sectional study. Stress Health. 2018;34(1):175-186. https://doi.org/10.1002/smi.2772

5. Rooke A. Posttraumatic stress and posttraumatic growth in New Zealand Surf Lifesavers: an analysis of age, gender, social support, \& selfefficacy: a thesis presented in partial fulfilment of the requirements for the degree of Master of Arts in Psychology at Massey University, New Zealand (Doctoral dissertation, Massey University; 2017.

6. Cénat JM, Derivois D. Assessment of prevalence and determinants of posttraumatic stress disorder and depression symptoms in adults survivors of earthquake in Haiti after 30 months. J Affect Disord. 2014;159:111-117. https://doi.org/10.1016/j.jad.2014.02.025

7. Terzi S. Secure attachment style, coping with stress and resilience among university students. J Happiness Well-Being. 2013;1(2): 97-109.

8. Newton-John Toby RO, Mason C, Hunter M. The role of resilience in adjustment and coping with chronic pain. Rehabil psychol. 2014;59(3): 360-365. https://doi.org/10.1037/a0037023

9. Calhoun LG, Tedeschi RG. The foundations of posttraumatic growth: An expanded framework. Handbook of posttraumatic growth. Routledge. 2014;17-37.

10. Lila M, Gracia E, Murgui S. Psychological adjustment and victim-blaming among intimate partner violence offenders: The role of social support and stressful life events. Eur J Psychol Appl Leg Context. 2013;5(2):147-153. https://doi.org/10.5093/ejpalc2013a4

11. Besser A, Neria Y. When home isn't a safe haven: Insecure attachment orientations, perceived social support, and PTSD symptoms among Israeli evacuees under missile threat. Psychol Trauma. 2012;4(1):34-46. https://doi.org/10.1037/a0017835

12. Morris BA, Shakespeare FJ, Rieck M, Newbery J. Multidimensional nature of posttraumatic growth in an Australian population. J Trauma Stress. 2005;18(5):575-585. https://doi.org/10.1002/jts.20067

13. Shin WY, Kim MG, Kim JH. Developing Measures of Resilience for Korean Adolescents and Testing Cross, Convergent, and Discriminant Validity. Stud Korean Youth. 2009;20(4):105-131.

14. Weiss DS, Marmar CR. The impact of event scale-revised. Ass Psychol Trauma PTSD. 1997:399-411.

15. Horowitz MJ, Wilner N, Alvarez W. Impact of event scale: A measure of subjective stress. Psychosom Med.1979;41(3):209218. https://doi.org/10.1097/00006842-197905000-00004

16. Eun HJ, Kwon TW, Lee SM, Kim TH, Choi MR, Cho SJ.A Study on Reliability and Validity of the Korean Version of Impact of Event ScaleRevised. Psychiatry Investig. 2005;44(3):303-310.

17. Zimet GD, Dahlem NW, Zimet SG, Farley GK. The multidimensional scale of perceived social support. J Pers Assess. 1988;52(1):30-41.

18. Joo SA. A study of PTSD of the subway operators with the experience of "person under train" incidents[Master's thesis]. Seoul, korea: Ewha Womans University; 2009.

19. Tedeschi RG, Calhoun LG. The posttraumatic growth inventory: Measuring the positive legacy of trauma. J Traumatic Stress. 1996;9(3):455471. https://doi.org/10.1007/bf02103658

20. Song SH, Lee HS, Park JH, Kim KH. Validity and reliability of the korean version of the posttraumatic growth inventory. Kor J Health Psychol. 2009;14(1):193-214. https://doi.org/10.17315/kjhp.2009.14.1.012

21. Schaefer LM, Howell KH, Schwartz LE, Bottomley JS, Crossnine CB. A concurrent examination of protective factors associated with resilience and posttraumatic growth following childhood victimization. Child Abuse Negl. 2018;85:17-27. https://doi.org/10.1016/j.chiabu.2018.08.019

22. Kilmer RP, Gil-Rivas V, Griese B, Hardy SJ, Hafstad GS, Alisic E. Posttraumatic growth in children and youth: clinical implications of an emerging research literature. Am J Orthopsychiatry. 2014;84(5):506-518. http://dx.doi.org/10.1037/ort0000016

23. Baillie SE, Sellwood W, Wisely JA. Post-traumatic growth in adults following a burn. Burns. 2014;40(6):1089-1096. https://doi.org/10.1016/j.burns.2014.04.007

24. Lindstrom CM, Cann A, Calhoun LG, Tedeschi RG. The relationship of core belief challenge, rumination, disclosure, and sociocultural elements to posttraumatic growth. Psychol Trauma. 2013;5(1):50-55. http://doi.org/10.1037/a0022030

25. CalhounLG, Tedeschi RG. The foundation of posttraumatic growth: An expanded framework. In: Calhoun LG \&Tedeschi RG, editors. Handbook of posttraumatic growth: Research and practice. Mahwah, NY: Lawrence Erlbaum Association. 2006:1-23.

Page $8 / 12$ 
26. Yu Y, Peng L, Chen L, Long L, He W, Li M, Wang T. Resilience and social support promote posttraumatic growth of women with infertility: The mediating role of positive coping. Psychiatry Res. 2014;215(2):401-405. https://doi.org/10.1016/j.psychres.2013.10.032

27. Volgin R, Bates G. Attachment and social support as predictors of posttraumatic stress and posttraumatic growth. Traumatol. 2016;22(3):184-191. https://doi.org/10.1037/trm0000083

28. Brooks M, Graham-Kevan N, Robinson S, Lowe M. Trauma characteristics and posttraumatic growth: The mediating role of avoidance coping, intrusive thoughts, and social support. Psychol Trauma. 2019;11(2):232-261. https://doi.org/10.1037/tra0000372

29. Setti I, Argentero P. Traumatization and PTSD in rescue workers: Prevention, assessment, and interventions. Compr Guide to PTSD. 2015:1-13. https://doi.org/10.1007/978-3-319-08613-2_78-1

\section{Figures}

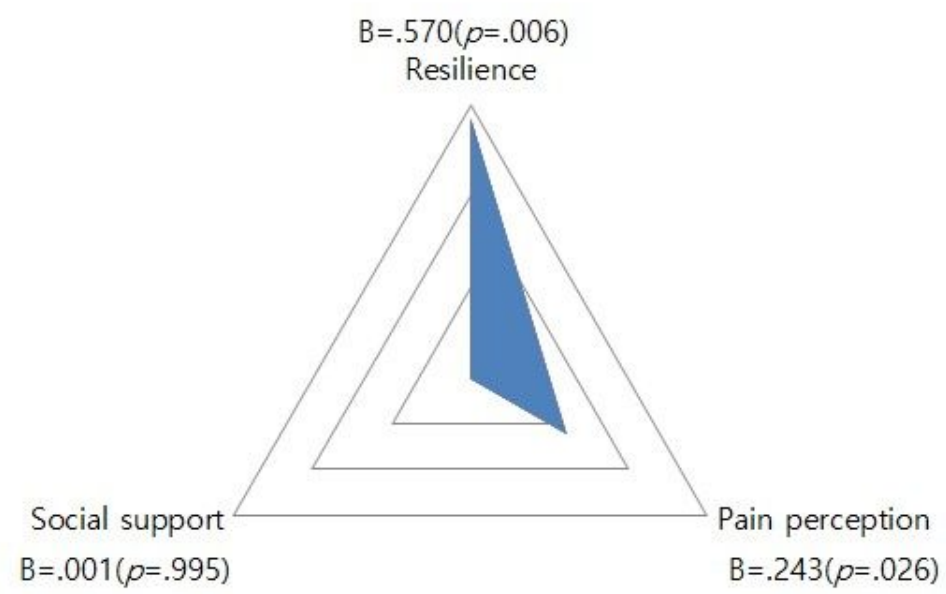

\section{Figure 1}

Resilience and pain perception are influential variables for police officers in their 20s. F=4.916 p=.004, R2=.211, Adj R2=.168 Fig 1. 20-29yrs :a

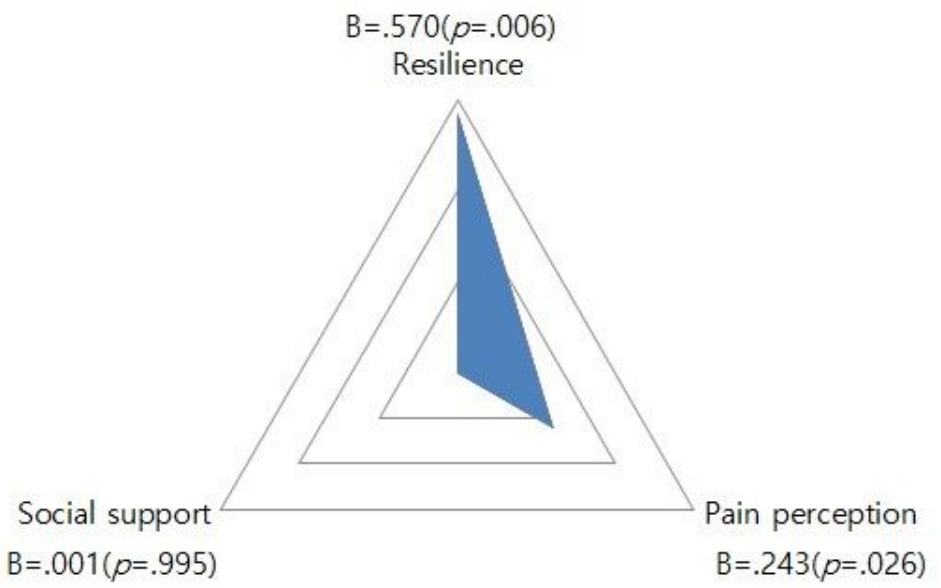

Figure 1 
Resilience and pain perception are influential variables for police officers in their 20s. F=4.916 p=.004, R2=.211, Adj R2=.168 Fig 1. 20-29yrs :a

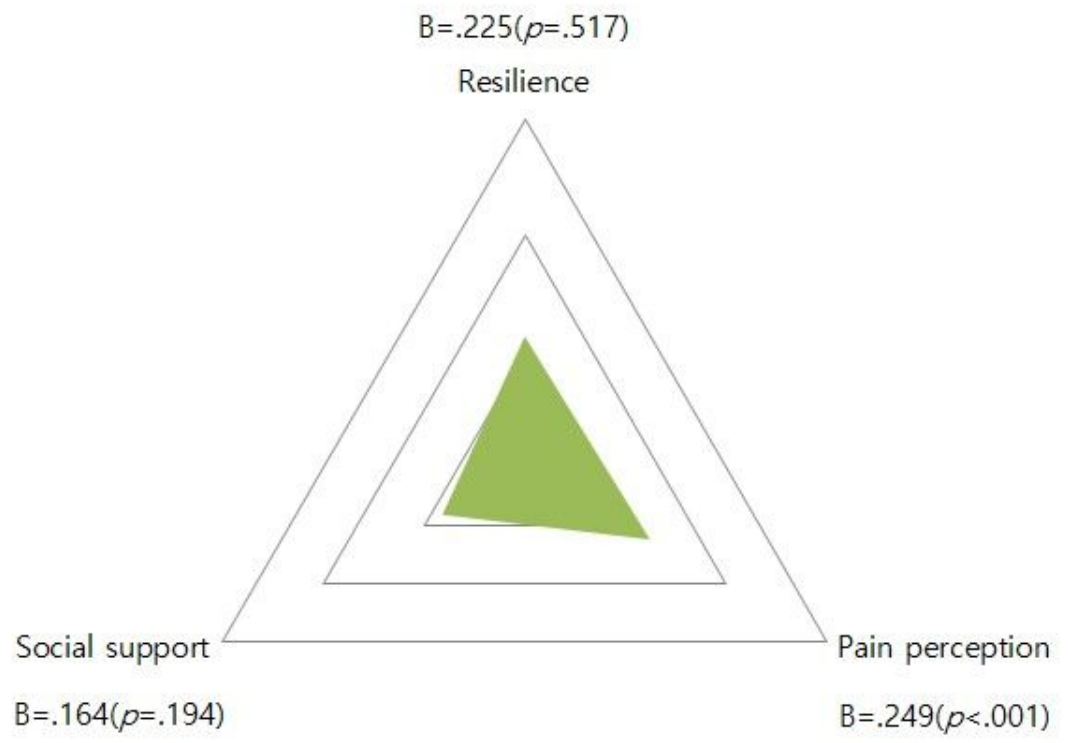

\section{Figure 2}

Pain perception is an influential variable for police officers in their 30s. F=7.527 $p<.001, R 2=.161$, Adj R2=.139 Fig 2. 30-39yrs :b

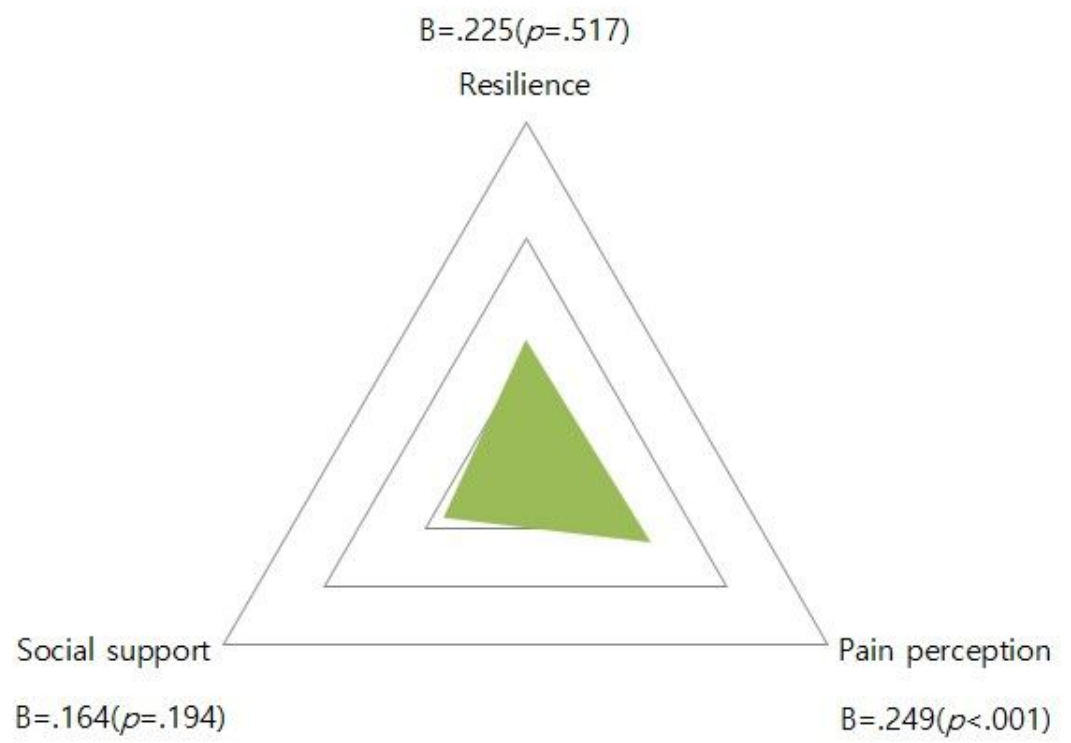

Figure 2

Pain perception is an influential variable for police officers in their 30s. F=7.527 p<.001, R2=.161, Adj R2=.139 Fig 2. 30-39yrs :b 


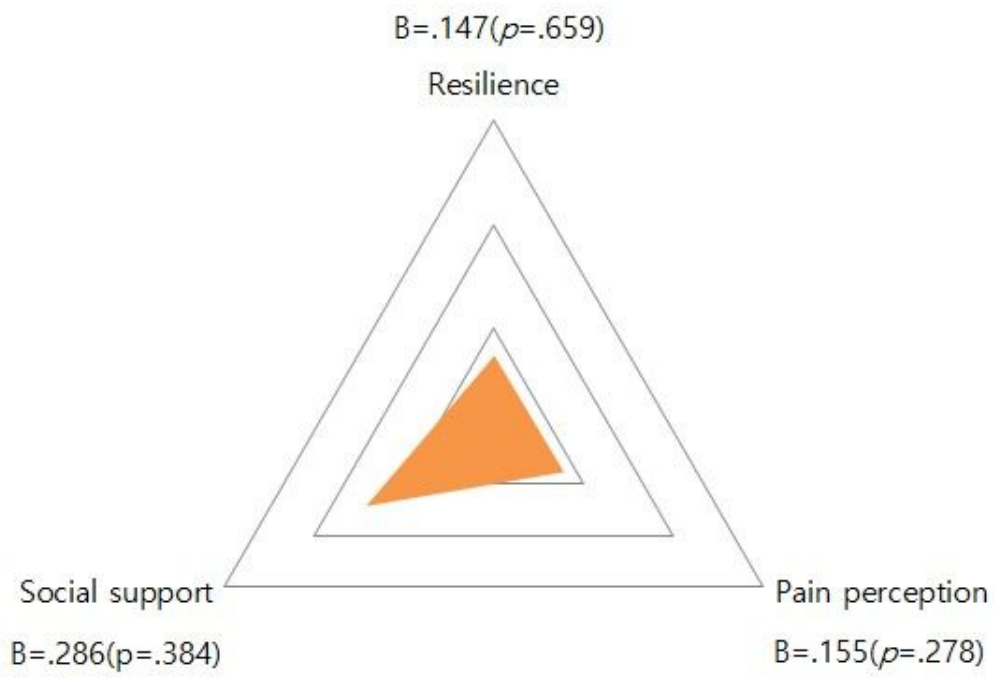

Figure 3

No variables were significantly influential for police officers in their 40s. F=.792 p=.507, R2=.069, Adj R2=.018 Fig 3. 40-49yrs :c

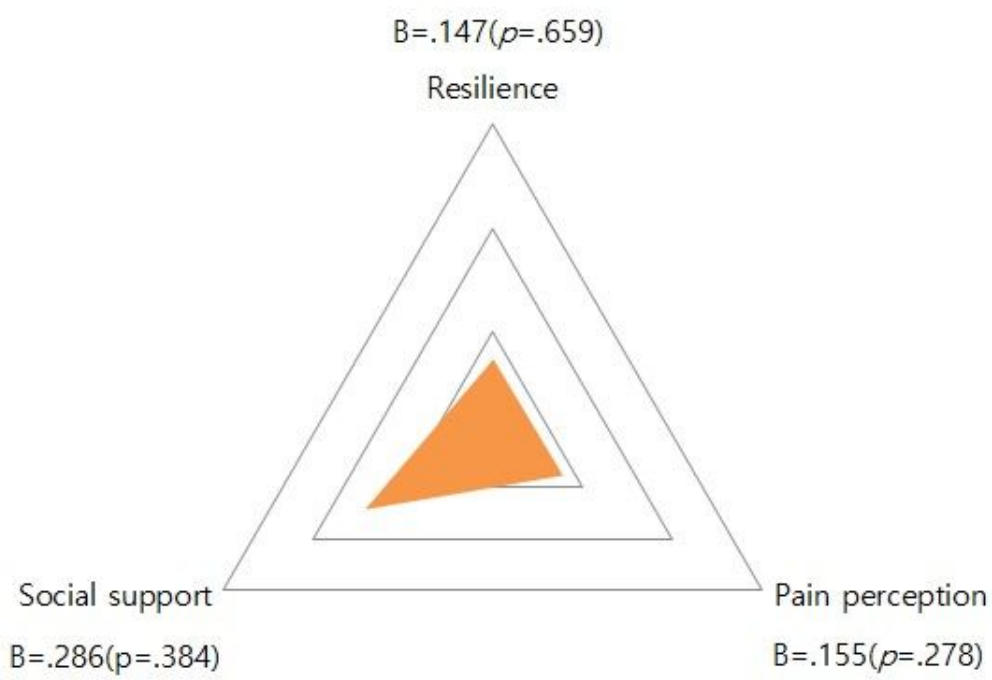

\section{Figure 3}

No variables were significantly influential for police officers in their 40s. F=.792 p=.507, R2=.069, Adj R2=.018 Fig 3. 40-49yrs :C 


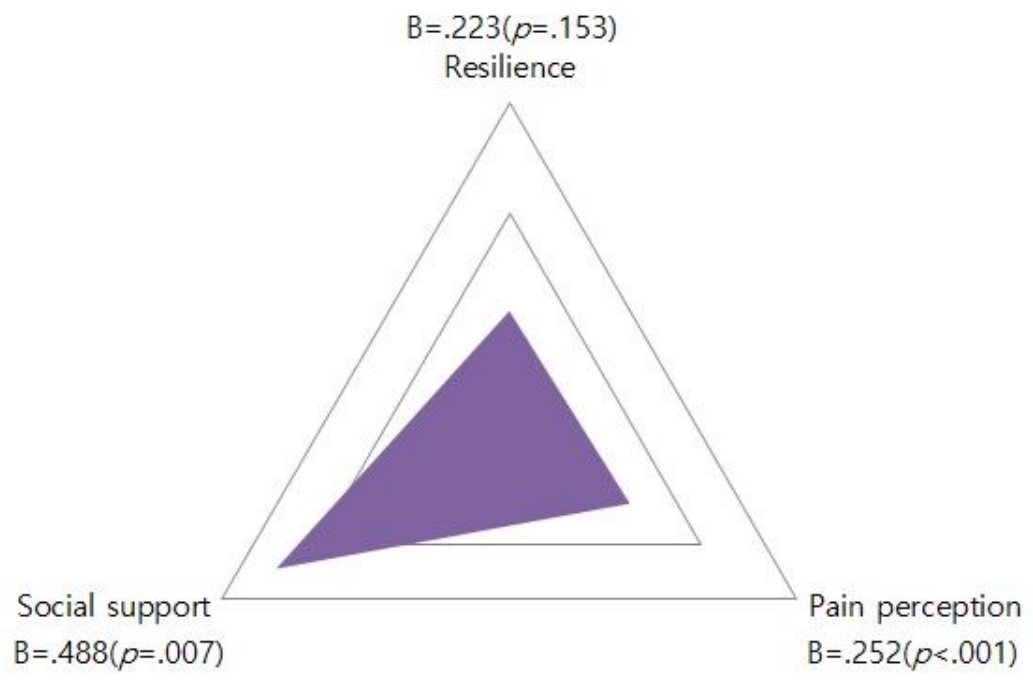

\section{Figure 4}

Social support and Pain perception were influential variables for police officers their 50 s and older. F=9.070 $p=<.001, R 2=.362$, Adj R2=.322 Fig 4 . $\geq 50 y r s$ :d

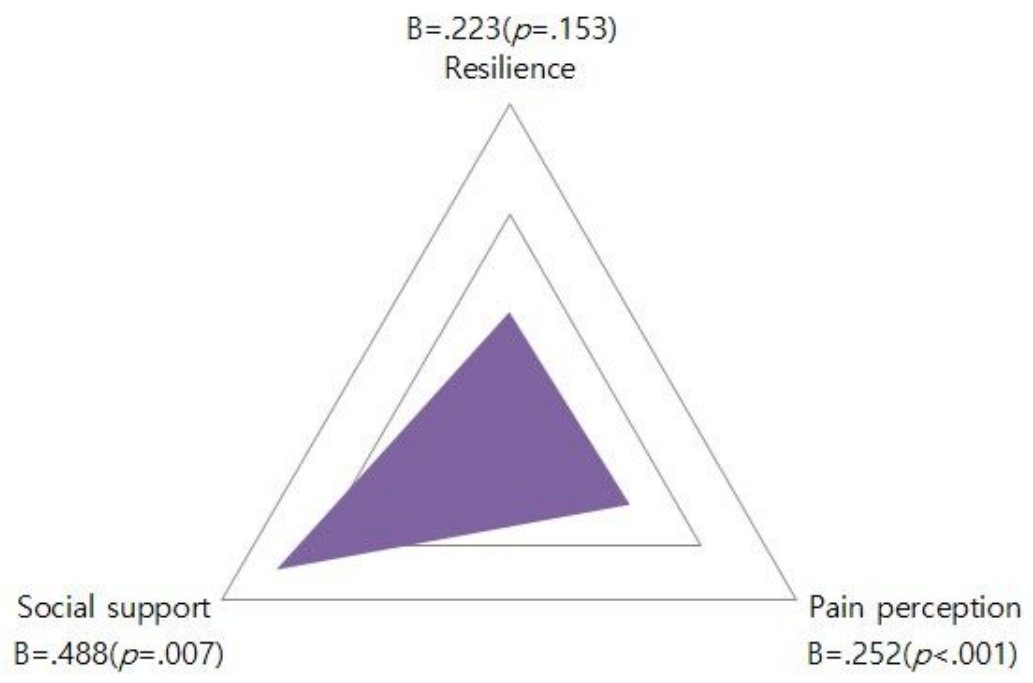

Figure 4

Social support and Pain perception were influential variables for police officers their 50 s and older. F=9.070 $p=<.001, R 2=.362$, Adj $R 2=.322$ Fig 4 . $\geq 50 \mathrm{yrs}: \mathrm{d}$ 